Island Studies Journal, Vol. 11, No. 1, 2016, pp. 9-34

\title{
Tools for sustainability assessment in island socio-ecological systems: an application to the Canary Islands
}

\author{
Isabel Banos-González. \\ University of Murcia, Murcia, Spain \\ $\&$ \\ University of Fribourg, Fribourg, Switzerland \\ ibbg1@um.es
}

Julia Martínez-Fernández

University of Murcia, Murcia, Spain

juliamf@um.es

and

Miguel Ángel Esteve

University of Murcia, Murcia, Spain

maesteve@um.es

\begin{abstract}
An integral dynamic model, in combination with other methods (indicators, policy and scenario analysis), is presented as a tool for sustainability assessment in island socio-ecological systems (SES). The Fuerteventura sustainability model (FSM), tested for the 1996-2011, allows a better understanding of the dynamic interactions between sustainability indicators and other factors of this island. The FSM was first applied to analyse the vulnerability of this island to climate change for the 2012-2025 period; results point to the need for urgent measures to mitigate its effects on some of the analysed indicators. A set of policy measures was then assessed from the behaviour of nine indicators and their sustainability thresholds. Finally, the FSM facilitated the development of a dynamic model of the island of El Hierro, extrapolating the features common to both SES. We propose this to be a useful tool for the quantitative sustainability assessment and the management of real island socio-ecological systems.
\end{abstract}

Keywords: Canary Islands, El Hierro, Fuerteventura, island socio-ecological systems, policy measures assessment, scenarios, sustainability indicators, system dynamic models

(C) 2016 - Institute of Island Studies, University of Prince Edward Island, Canada

\section{Introduction: sustainability in island socio-ecological systems}

There is an increasing interest in the assessment of sustainability in island socio-ecological systems (Baldacchino, 2006; Petrosillo, Costanza, Aretano, et al., 2013). This may be due to the large potential of islands as observatories of sustainability, where the close interaction between ecological aspects and socio-economic processes is explicitly acknowledged. 
Socio-ecological systems (SES) can be defined as integrated systems of ecosystems and human society, with reciprocal feedback (Anderies, Janssen \& Ostrom, 2004; Halliday and Glaser, 2011). These interacting components form a complex and dynamic entity, the analysis of which requires a holistic approach (Hodbod \& Adger, 2014; Hidalgo, Ther, Saavedra, \& Díaz, 2015).

Non-sustainable trends in the evolution of SES have stimulated a search for new approaches towards the better understanding of the complex and problematic relationship between the environment and development (UNEP, 2002). The current application of sustainable policies in SES is quite far from what is required. Several barriers and difficulties explain this gap between knowledge and action:

i) Despite the increasing recognition of the close inter-dependencies between the economic, environmental and social components, in practice, these dimensions are frequently considered separately.

ii) There is a lack of adequate tools to understand, assess and communicate the best options for more sustainable systems and to share visions among policy makers, stakeholders and other agents, based on sound scientific knowledge.

iii) There is a need for SES which can be used to demonstrate the effect of general policies regarding sustainability.

Decisions to modify any aspect of a socio-ecological system may have unintended effects, perhaps with time delays, which may aggravate the original problem or create more challenging issues. In this sense, a systemic perspective provides a framework for managing change and complexity by understanding the dynamic interactions, delays and feedbacks embedded in complex systems (Fong et al., 2009).

System dynamics, a thinking-model and simulation methodology developed by Forrester (1961), has proved useful in the study of various SES (Pérez et al., 2012; MartínezFernández et al., 2013) and, specifically, in facilitating the search for integrated management in island SES (González et al., 2008; Jørgensen, 2013). Furthermore, system dynamic models (SDMs) enable decision makers to anticipate the long-term consequences of their decisions and actions.

Many approaches to sustainability have been based on indicators (Bell \& Morse, 2005; van Zeijl-Rozema et al., 2011). Schneider et al. (2014) considered that indicators provide a reasonably simple tool that allows the analysis and communication of complex ideas by condensing their multifaceted nature into a manageable amount of meaningful information. Indicators provide decision-makers with an evaluation of integral SES, with short- and longterm perspectives, in order to determine which actions should or should not be taken in an attempt to make systems more sustainable (EEA, 2012).

Moreover, scenario development, including policy options, is one of the major tools used to visualise and compare the potential outcomes of a variety of policies developed to meet sustainability objectives, as well as to anticipate the long-term consequences of policy decisions and actions (Zhang et al., 2015).

Finally, islands may be considered as potential laboratories for any action that may alter sustainability (Baldacchino, 2013). Several advantages have been identified, regarding sustainability analysis and modelling, in island systems (Baldacchino, 2006; Jørgensen, 2013; 
Petrosillo et al., 2013): i) they facilitate the assessment of energy and material flows due to their physical boundaries; ii) they are often particularly vulnerable regarding natural resources such as water and energy; and iii) islands represent an opportunity for a more thorough control of intervening variables, which then are more likely to guarantee successful outcomes.

This paper explores the potential for developing an integral tool for sustainability assessment, useful for the management of actual island SES. This is addressed by developing, testing and applying an integral dynamic sustainability model, in combination with other methods and approaches (indicators, policy and scenario analysis), to provide a tool for prospective analysis and to assist the decision making process in SES. In this work, we apply this methodology, albeit with a different degree of development, to two islands of the Canaries archipelago: Fuerteventura and El Hierro (Figure 1). These two biosphere reserves represent good examples of the extremes of the climatic and ecological gradient of the archipelago, as described in more detail below.

The specific aims of this work are: i) to develop an integral model which incorporates the factors and key processes of a socio-ecological system, in this case, the Fuerteventura sustainability model (FSM); ii) to include the most relevant sustainability indicators in the model, as a tool to analyse the main changes and the interactions between these factors and indicators; iii) to use the model to analyse the vulnerability of this island to external changes, such as climate change; iv) to apply the model to assess how some of these sustainability indicators react under a set of policy measures; and v) to use this model as the basis to develop a dynamic model of El Hierro.

\section{Description of the case studies}

The Canary Islands, located between $27^{\circ} 37^{\prime}-29^{\circ} 25^{\prime} \mathrm{N}$ and $13^{\circ} 20^{\prime}-18^{\circ} 10^{\prime} \mathrm{W}$ (Figure 1), occupy a combined land surface area of 7,436 $\mathrm{km}^{2}$ (GRAFCAN, 2011). It is a volcanic archipelago composed of seven major islands. There is a progression of age from the easternmost islands (Lanzarote and Fuerteventura), the oldest and most eroded, to the westernmost (El Hierro), which are steeper and more rugged (del Arco et al., 2010).

\section{Figure 1: Location of the study area: El Hierro (West) and Fuerteventura (East), Canary Islands, Spain.}

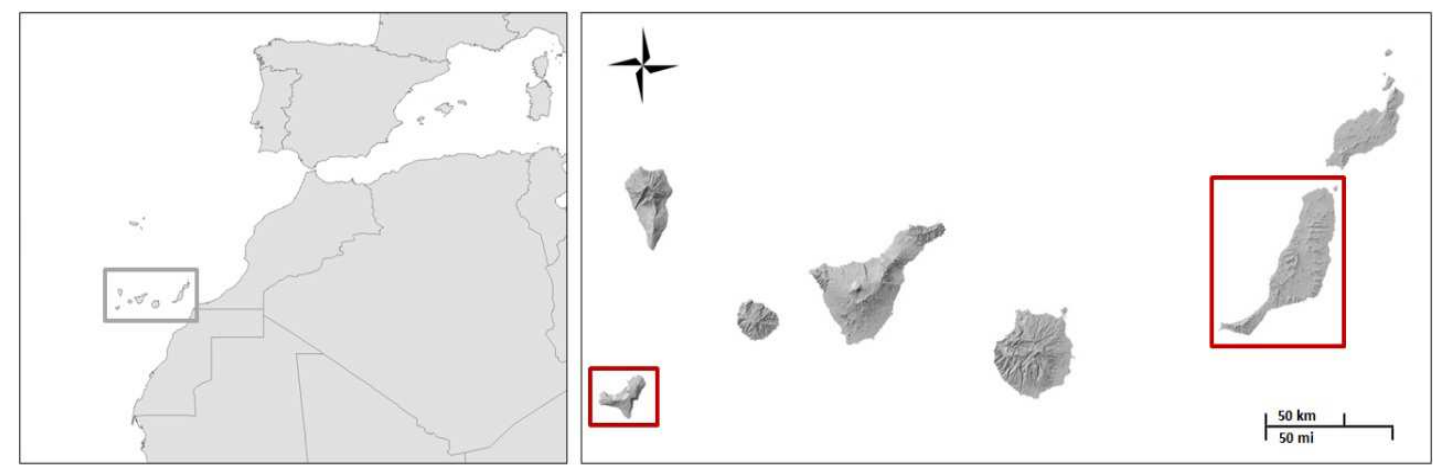

Source: ASTER Global Digital Elevation Model (ASTER GDEM). 
Fuerteventura, with a land area of $1,655 \mathrm{~km}^{2}$, is the nearest of the islands to the African continent, about $100 \mathrm{~km}$ away, and is the most arid. It has a hyperarid climate (Torres Cabrera, 1995), with an average annual rainfall below $120 \mathrm{~mm}$. The vegetation is dominated by xerophytic scrubs and annual grasslands (Schuster et al., 2012). In recent decades, the traditional productive activities (ranching, artisanal fishing and non-irrigated land farming in gavias $^{1}$ ) have been mainly substituted by tourism and related activities.

Fuerteventura, declared a Biosphere Reserve in 2009 (UNESCO, 2009), is known for its beaches, which can be found all over the coast. The number of tourist arrivals grew by $374 \%$ from 1990 to 2010, when the island received almost 1.5 million foreign tourists (Government of the Canary Islands, 2010), turning tourism into the main driving force of the socioeconomic and environmental changes in the last years. These rapid changes are leading to the emergence of new socio-ecological requirements, which should be urgently addressed.

El Hierro, declared a Biosphere Reserve in 2000 (UNESCO, 2000), is the smallest (278 $\mathrm{km}^{2}$ ) and least inhabited (10,675 inhabitants) of the Canary Islands (ISTAC, 2014). Since the early 1990s, the traditional productive activities (agriculture, ranching and artisanal fishing) have been mainly substituted by the service sector, although, unlike the other islands of the archipelago, with a limited participation of tourism (Bueno and Carta, 2005; MartínFernández, 2009). One of the main challenges within the Biosphere Reserve declaration was the commitment of El Hierro to become an island that is $100 \%$ renewable. According to Iglesias and Carvallo (2011), some features of the island have made the presence of renewable energy easier: i) the island is endowed with two natural commodities of the greatest interest: waves and wind; ii) there is considerable consensus among its population and policy makers in support of renewable energy. These favourable conditions facilitated the development of the "El Hierro Hydro-Wind Plant" project, aimed at the construction of a hydro-wind system able to cover the electricity demand of this island, making it a territory that is self-supplied in terms of electricity, strictly through renewable sources (see Gorona del Viento, 2015, for details).

A fuller description of the islands is provided below, along with the descriptions of their models.

\section{Methodology}

\section{Modelling process}

The iterative process to elaborate an integral model starts with the development of a conceptual model for the case of study, determining the factors and key processes of the sustainability of the system, their interactions and feedbacks (Figure 2). The conceptualising phase of the FSM was carried out using the results of the XIth Atlantic Conference of the Environment (held in May 2011) at which the most relevant themes for sustainability were identified with the participation of a panel of experts. In relation to these results, a set of sustainability indicators, also derived from a proposal of the Fuerteventura Cabildo - the island council (Cáceres, 2010) - and in line with the sustainability aims of the AP (Action Plan, 2013), was integrated in the model, in order to facilitate the diagnosis and to analyse the

${ }^{1}$ Gavias are traditional runoff-capture farming systems (Díaz et al., 2011). This strategy seeks to increase water availability for crops by means of capturing runoff generated during rainstorms, in levelled and dammed plots used as cropping areas. 
progress of and open challenges to the sustainability of the island. These indicators meet the basic characteristics suggested by Bell and Morse (2008): relevance, ease of interpretation of the results, simplicity, low redundancy and utility for communication with non-scientific agents. Then, all the model variables and parameters were defined and formulated, starting from scientific literature and the available information. The FSM was constructed following the system dynamics methodology (Forrester, 1961) and using the Vensim software (Ventana Systems, 2011). Once the model is tested and calibrated, it can be applied to explore its future behaviour under different scenarios and policy measures.

\section{Figure 2: Simplified diagram of the methodological approach.}

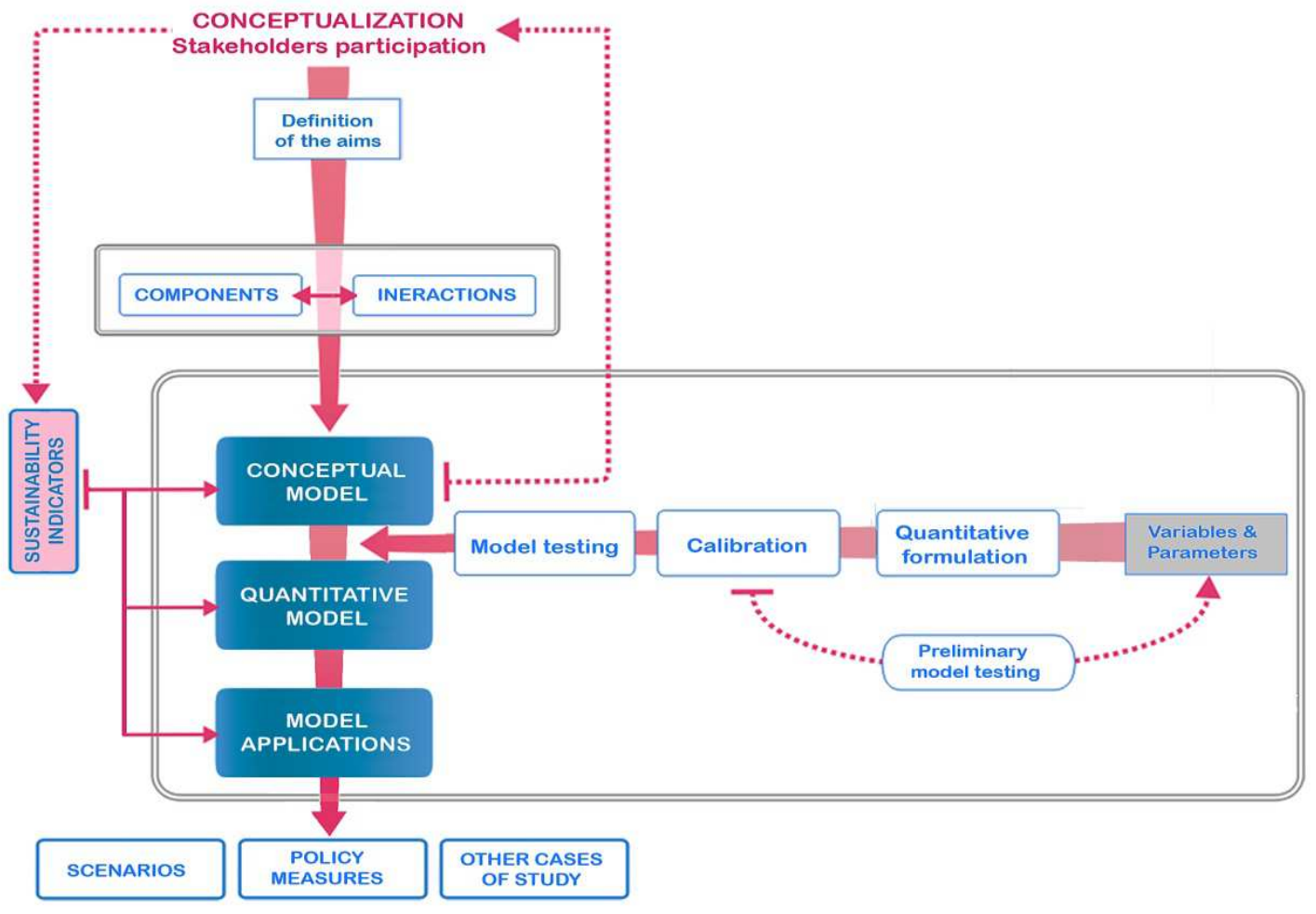

Assessing how sustainability indicators react under different scenarios and policy measures.

In this paper, the way in which a selection of nine indicators would react over the 2012-2025 period under different scenarios and policy measures was determined. These nine indicators were selected based on their relationships with the policies and scenarios involved and on the information available about their thresholds (Table 1). According to several authors (Gallopin, 1997; Moldan et al., 2012), the identification of reference values is the most attractive way to monitor progress towards sustainability over time, which may increase the influence of indicators on the adoption of sustainable policies. In the FSM, when there were no published references for an indicator, the threshold was established based on a proportion of the value adopted for that indicator in 2009, when Fuerteventura was declared a Biosphere Reserve 
(UNESCO, 2009). This proportion, related to the concept of "Limit of Acceptable Change" (LAC ${ }^{2}$, Diedrich et al., 2011), was set for this work as $75 \%^{3}$ of the 2009 value, since this proportion allows certain change due to socio-touristic dynamics, but the threshold is still far from compromising the conservation goals.

Table 1: Selected sustainability indicators included in the Fuerteventura sustainability model and their thresholds.

\begin{tabular}{|c|c|c|c|c|}
\hline Indicators & Units & Threshold & Meaning of the threshold & $\begin{array}{c}\text { References of the } \\
\text { thresholds }\end{array}$ \\
\hline $\begin{array}{l}\text { Ratio between tourist } \\
\text { accommodation and } \\
\text { resident population } \\
\text { (ear) }\end{array}$ & $\begin{array}{c}\text { Touristic } \\
\text { bed/inhabitant }\end{array}$ & $<0.97$ & $\begin{array}{c}\text { Ratio between tourist } \\
\text { accommodation and resident } \\
\text { population }\end{array}$ & $\begin{array}{l}\text { Government of the } \\
\text { Canary Islands } \\
\text { (2008) }\end{array}$ \\
\hline $\begin{array}{c}\text { Artificial land } \\
\text { proportion }(a l p)\end{array}$ & $\%$ & $<20$ & $\begin{array}{l}\text { Percentage of land modified } \\
\text { (agriculture, urban, } \\
\text { infrastructures) }\end{array}$ & $\begin{array}{l}\text { Graymore et al. } \\
\text { (2010) }\end{array}$ \\
\hline $\begin{array}{c}\text { High quality } \\
\text { vegetation proportion } \\
(h q p) \\
\end{array}$ & Dimensionless & LAC $>0.1394$ & $\begin{array}{l}0.139 \text { represents the LAC } \\
(75 \% \text { of the value in } 2009)\end{array}$ & $\begin{array}{l}\text { Model value in } \\
2009\end{array}$ \\
\hline $\begin{array}{l}\text { Overgrazing indicator } \\
(\text { o } i)\end{array}$ & Dimensionless & $<1$ & $\begin{array}{c}\text { Values above } 1 \text { mean } \\
\text { overgrazing }\end{array}$ & $\begin{array}{c}\text { Banos-González et } \\
\text { al. (2015) }\end{array}$ \\
\hline $\begin{array}{l}\text { Houbara habitat } \\
\text { proportion }(h h p)\end{array}$ & Dimensionless & $\mathrm{LAC}>0.75$ & $\begin{array}{l}0.75 \text { is the Limit of } \\
\text { Acceptable Change ( } 75 \% \text { of } \\
\text { the } 2009 \text { value) }\end{array}$ & $\begin{array}{l}\text { Model value in } \\
2009\end{array}$ \\
\hline $\begin{array}{c}\text { Egyptian vulture } \\
\text { population proportion } \\
(\text { evp })\end{array}$ & Dimensionless & $\mathrm{LAC}>0.75$ & $\begin{array}{c}0.75 \text { is the Limit of } \\
\text { Acceptable Change ( } 75 \% \text { of } \\
\text { the } 2009 \text { value) }\end{array}$ & $\begin{array}{l}\text { Model value in } \\
2009\end{array}$ \\
\hline $\begin{array}{l}\text { Per capita primary } \\
\text { energy consumption } \\
\text { (pepc) }\end{array}$ & GJ/ Year*pc & $<42$ & $\begin{array}{l}\text { Minimum energy use } \\
\text { required to reach a Human } \\
\text { Development Index of at least } \\
0.8 \text {, as recommended by } \\
\text { UNDP. }\end{array}$ & $\begin{array}{l}\text { Johansson \& } \\
\text { Goldemberg } \\
\quad(2008)\end{array}$ \\
\hline $\begin{array}{l}\text { Per capita } \mathrm{CO}_{2} \\
\text { emissions } \\
\quad\left(\mathrm{CO}_{2} p c\right)\end{array}$ & $\begin{array}{l}\text { metric tonnes } \\
\mathrm{CO}_{2} / \text { Year*pc }\end{array}$ & $<9.52$ & $\begin{array}{c}\text { A } 20 \% \text { reduction in the per } \\
\text { capita } \mathrm{CO}_{2} \text { emissions from } \\
1990 \text { levels. Based on } 1999 \\
\text { value. }\end{array}$ & EC (2008) \\
\hline $\begin{array}{c}\text { Share of renewable } \\
\text { energy (ser) }\end{array}$ & $\%$ & $>0.2$ & $\begin{array}{c}\text { A share of renewable energy } \\
\text { of at least } 20 \% \text { in } 2020 \text { and } \\
27 \% \text { in } 2030 .\end{array}$ & $\mathrm{EC}(2008,2015)$ \\
\hline
\end{tabular}

\footnotetext{
${ }^{2}$ The Limit of Acceptable Change is understood as the amount of change to be allowed to occur, since actions of conservation and development should coexist in areas such as the BRs.

${ }^{3}$ It should be noted that this value of $75 \%$ refers to land outside the Protected Areas, since no land use changes occurred within them.
} 
Description of the scenarios and policy measures

A tool for adaptive governance and improving resources management should include the capacity to deal with changes, including external drivers. In order to incorporate a preliminary assessment of this capacity into our analysis, two climatic scenarios and two policy measures, proposed by diverse agents, were explored:

- Climate change scenarios. The A2 and B2 scenarios from the Intergovernmental Panel on Climate Change Special Report on Emission Scenarios (Nakicenovic \& Swart, 2000) have been considered. In the FSM, model parameters were calculated on the basis of the CEDEX report (2011) for the A2 and B2 scenarios. This means a $10 \%$ decrease in annual rainfall and $13 \%$ increase in irrigation requirements in 2025 for A2. For B2, the decrease in annual rainfall would be $14 \%$ and the increase in irrigation requirements would amount to $18 \%$.

- Measure I (M.I). This measure would consist of covering $100 \%$ of the electricity demand for the desalinated water supply with renewable energy in 2025. This measure represents one of the basic guidelines of the Biosphere Reserve (AP 2013 and per. com), due to the rising consumption of electrical energy in the supply of this basic resource.

- Measure II (M.II). Since in the FSM, the increase in the number of new tourist accommodations depends on the threshold of the occupancy rate, among other variables, this measure would consist of the limitation of the construction of new tourist accommodations, by increasing the threshold of the occupancy rate to $75 \%$ of existing tourist accommodation (Government of the Canary Islands, 2008).

\section{Results}

\section{Model description}

The FSM (Figure 3) is an integral system dynamics model (Forrester, 1961) which facilitates the understanding of the structure and behaviour of this complex system by means of the causal relationships, feedback loops, delays and others. The process of simulation in dynamic models is carried out by difference equations, using discrete time steps (Kelly et al., 2013; Martínez-Moyano \& Richardson, 2013). The behaviour of the variables can be determined by the use of the model, simulating the change in their values over the time.

The model is structured in five sectors: Socio-touristic, Land Uses, Biodiversity, Environmental Quality and Water Resources (Figure 3). Among the 520 model variables included, 37 represent sustainability indicators which were integrated in the model (Table 2). The formulation of the model variables and parameter values can be consulted in the Supplementary material.

\section{The socio-tourist sector}

This sector includes the dynamics of the resident and tourist population. Tourism represents the main driving force of the employment and wealth generation in Fuerteventura. The modelling of one of the key factors, the tourist equivalent population (etp), was calculated based on the following factors: the GDP evolution of the most important markets for outbound 
tourism for the island (Garín-Muñoz, 2006); the tourist accommodation offer (Cruz, 2009); the available beach per capita (Santana-Jiménez \& Hernández, 2011); and the tourist prices index of the island (Wei et al., 2013). The etp drives other indicators, such as the occupancy rate and the tourist employment ratio. The former determines the creation of new tourist accommodations. The latter, as on other islands (Kitrinou \& Mytilini, 2014; Pons et al., 2014), strongly influences migratory flows, and it represents an average of $33 \%$ of the total employment in Fuerteventura (ISTAC, 2012).

Figure 3: Overview of Fuerteventura sustainability model, showing the key variables of the five sectors.

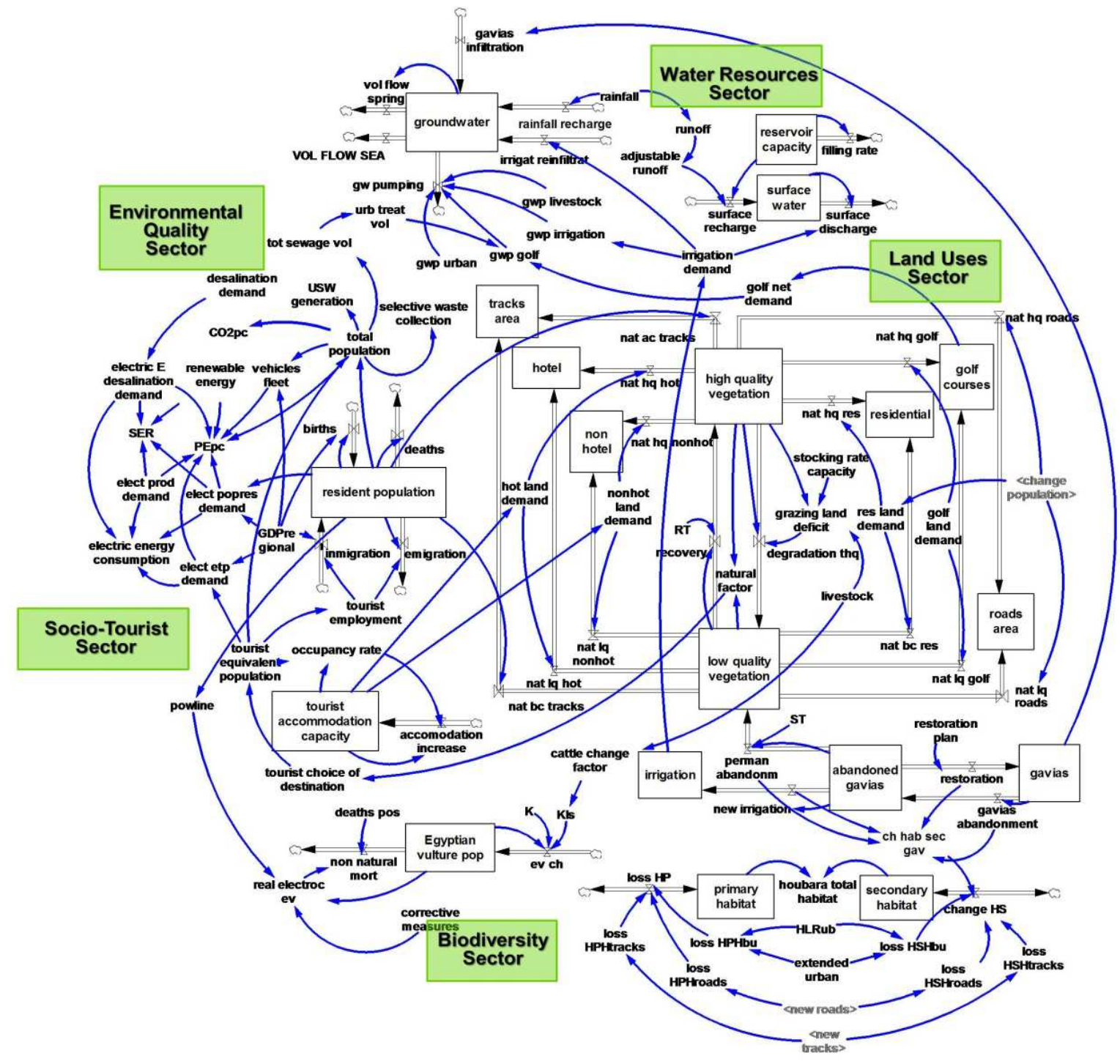


Table 2: Sustainability indicators integrated in the FSM and HSM.

\begin{tabular}{|c|c|c|c|}
\hline Sectors & Indicator & Units & $\begin{array}{c}\text { Integrated in FSM } \\
\text { or in HSM }\end{array}$ \\
\hline \multirow{8}{*}{ 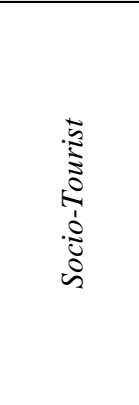 } & Population growth rate & $\%$ & FSM, HSM \\
\hline & Population density & Inhabitants $/ \mathrm{km}$ & FSM, HSM \\
\hline & Occupancy rate & $\%$ & FSM, HSM \\
\hline & Tourist attraction index & Dimensionless (dmls) & FSM, HSM \\
\hline & Tourist choice of destination & dmls & FSM, HSM \\
\hline & $\begin{array}{l}\text { Ratio between tourist beds \& resident } \\
\text { population }\end{array}$ & $\begin{array}{c}\text { Tourist } \\
\text { beds/inhabitant }\end{array}$ & FSM, HSM \\
\hline & Tourist employment ratio & $\%$ & FSM, HSM \\
\hline & Resident-tourist ratio & $\mathrm{dmls}$ & FSM, HSM \\
\hline \multirow{8}{*}{ 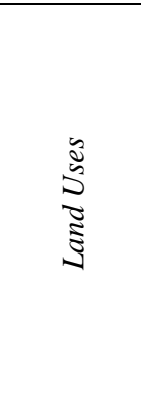 } & Artificial land proportion & $\%$ & FSM, HSM \\
\hline & $\begin{array}{l}\text { Non-protected area with high environmental } \\
\text { functionality proportion }\end{array}$ & dmls & FSM, HSM \\
\hline & Fodder importation needs proportion & dmls & FSM \\
\hline & Landscape indicator & $\mathrm{dmls}$ & FSM, HSM \\
\hline & High quality vegetation area proportion & $\mathrm{dmls}$ & FSM \\
\hline & Overgrazing indicator & dmls & FSM, HSM \\
\hline & Roads density & $\mathrm{km} / \mathrm{km}^{2}$ & FSM, HSM \\
\hline & Beach per capita & $\mathrm{m}^{2} /$ inhab & FSM, HSM \\
\hline \multirow{7}{*}{$\begin{array}{l}\vec{\Xi} \\
\vdots \\
\vdots \\
\vdots \\
\vdots \\
\vdots \\
0 \\
0\end{array}$} & Houbara habitat proportion & dmls & FSM \\
\hline & Egyptian vulture population proportion & dmls & FSM \\
\hline & Key species deaths by electrocution & Individuals/year & FSM, HSM \\
\hline & Protected area proportion & $\%$ & FSM, HSM \\
\hline & Spanish Juniper proportion & $\%$ & HSM \\
\hline & Evergreen Laurel forests proportion & $\%$ & HSM \\
\hline & Canaries Pinegrove proportion & $\%$ & HSM \\
\hline \multirow{9}{*}{ 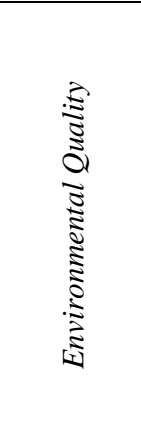 } & Motorisation index & vehicle/inhab/year & FSM, HSM \\
\hline & Share of renewable energy & $\%$ & FSM, HSM \\
\hline & Per capita $\mathrm{CO}_{2}$ emissions & $\begin{array}{l}\text { Metric tonnes } \mathrm{CO}_{2} / \\
\text { inhab/year }\end{array}$ & FSM, HSM \\
\hline & Per capita primary energy consumption & GJ/inhab/year & FSM, HSM \\
\hline & Per capita electric energy consumption & GJ/inhab/year & FSM, HSM \\
\hline & Per capita USW generation & $\mathrm{kg} /$ inhab/year & FSM, HSM \\
\hline & Selective waste management index & $\mathrm{kg} /$ year & FSM, HSM \\
\hline & Recycling rate of waste extracted from mix & $\%$ & FSM, HSM \\
\hline & Per capita waste neither reused nor recycled & $\mathrm{kg} /$ inhab/year & FSM, HSM \\
\hline \multirow{9}{*}{ 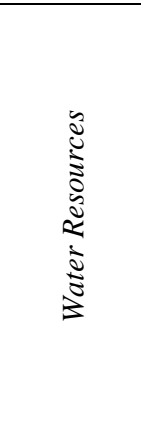 } & Resident water consumption & $\mathrm{m}^{3} /$ inhab/year & FSM, HSM \\
\hline & Tourist water consumption & $\mathrm{m}^{3} /$ inhab/year & FSM, HSM \\
\hline & Total gross water demand & $\mathrm{m}^{3} /$ year & FSM, HSM \\
\hline & Proportion of waste water treatment & $\%$ & FSM, HSM \\
\hline & Proportion of waste water reused & $\%$ & FSM, HSM \\
\hline & $\begin{array}{l}\text { Proportion of rainwater catchment \& fog } \\
\text { collection }\end{array}$ & $\%$ & HSM \\
\hline & Energy consumption in seawater desalination & Kwh/year & FSM, HSM \\
\hline & Losses in water distribution network & $\%$ & FSM, HSM \\
\hline & Aquifer recharge & $\mathrm{m}^{3} /$ year & FSM, HSM \\
\hline
\end{tabular}




\section{The land uses sector}

The population growth, both tourist equivalent and resident, has triggered the rise in the area occupied by urban built-up areas (residential, hotel and non-hotel) and infrastructures (roads and tracks). Besides, Fuerteventura has witnessed a gradual loss of the traditional agrosystems called gavias. Due to the important environmental functions of the gavias, such as landscape enhancement, organic nutrients and water retention and aquifer recharge (Díaz et al., 2011), the Cabildo promoted the implementation of an Abandoned Gavias Restoration Plan (Fuerteventura Cabildo, 2009).

The island is facing a vegetation degradation problem. Some authors suggest that grazing by cattle is primarily responsible (Gangoso et al., 2006; Schuster et al., 2012). In our model, the overgrazing effect was formulated based on the maximum stocking rate capacity offered by the territory, highly dependent on the annual rainfall, as well as on the proportion of livestock which actually grazes. When grazing exceeds the sustainable stocking rate capacity, degradation of the high quality vegetation occurs.

\section{The biodiversity sector}

The biodiversity sector, or flagship species sector, is focused on two endangered and endemic bird subspecies of Canary Islands (BirdLife, 2004; Lorenzo, 2004): the Canarian Houbara Bustard (Chlamydotis undulata fuerteventurae) and the Egyptian vulture (Neophron percnopterus majorensis). Both are very representative animal species of the island, with a specific mention in the Action Plan (2013). Their modelling enables us to know the extent to which changes that happen on the island affect these species. Whereas the habitat loss due to urban uses, roads, tracks and active crops is the main factor threatening the habitat and population of the Canarian Houbara on the island (Carrascal et al., 2008; Banos-González et al., 2016), poisonings and electrocutions represent the main threats to the vultures (Palacios, 2000; Donázar et al., 2002).

\section{The environmental quality sector}

The different energy demands - of tourist and resident populations, transport, productive activities and the desalination process - have been taken into account in the development of this sector. The model also allows the quantification of some indicators, such as the per capita $\mathrm{CO}_{2}$ emission of the island and the share of renewable energies (Denis \& Parker, 2009), which on Fuerteventura are mainly wind power, solar thermal and photovoltaic.

In the case of urban waste management, the efficiency of the separation and the recycling and quantity of waste left in the dump have both been considered (Cáceres, 2010).

\section{The water resources sector}

This model sector was built taking into account the differentiated demands of: irrigation, livestock, golf courses and resident and tourist consumption. The surface resources are not enough to satisfy the population demands or the irrigation requirements. Groundwater resources, predominantly brackish (Herrera \& Custodio, 2000), supply only a small proportion of total agricultural and farming needs (CIAFV, 2009). This gives an idea of the importance of the role played by desalination in meeting total water demand (Cabrera \& Custodio, 2012) and 
of the island's dependence on energy consumption, even with regard to the supply of a basic need such as water.

\section{Model testing}

A set of model testing procedures was applied (Barlas, 1996), including: sensitivity analysis, extreme conditions test and a 'goodness of fit' test.

The sensitivity analysis, very useful to assess the model's robustness, was carried out using different sensitivity analysis techniques, ranging from "One factor at a time" techniques (Sun et al., 2012) to general sensitivity techniques (Lesnoff et al., 2012). Sensitivity analysis results supported the robustness of the model's behaviour.

In relation to extreme condition tests ( $\mathrm{Li}$ et al., 2012), the model generated the expected results when it was subjected to 25 extreme conditions, such as an unexpected drop in tourist arrivals, extreme droughts or an increase in grazing (Figure 4).

Figure 4: Simulation of the extreme conditions test: "An accelerated demand for built-up land leads to a reduction in houbara habitat". a) Input conditions; b) Expected effects.

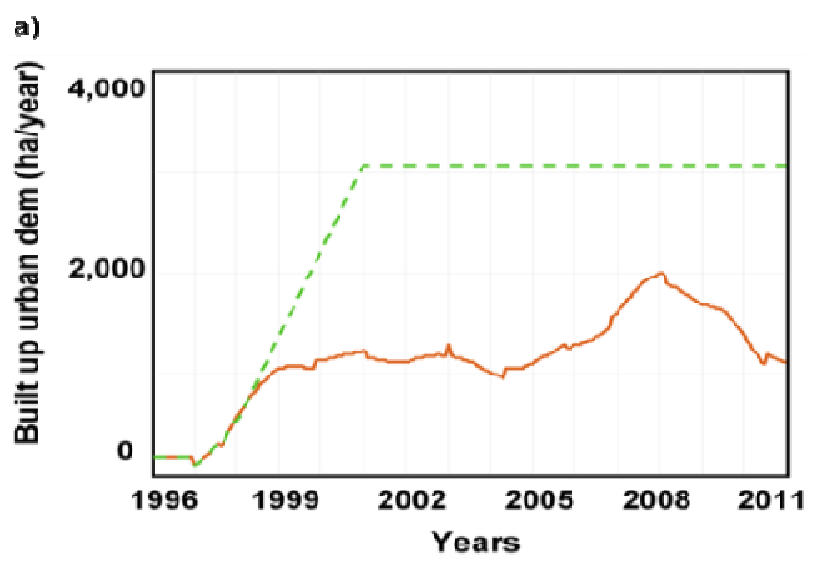

b)

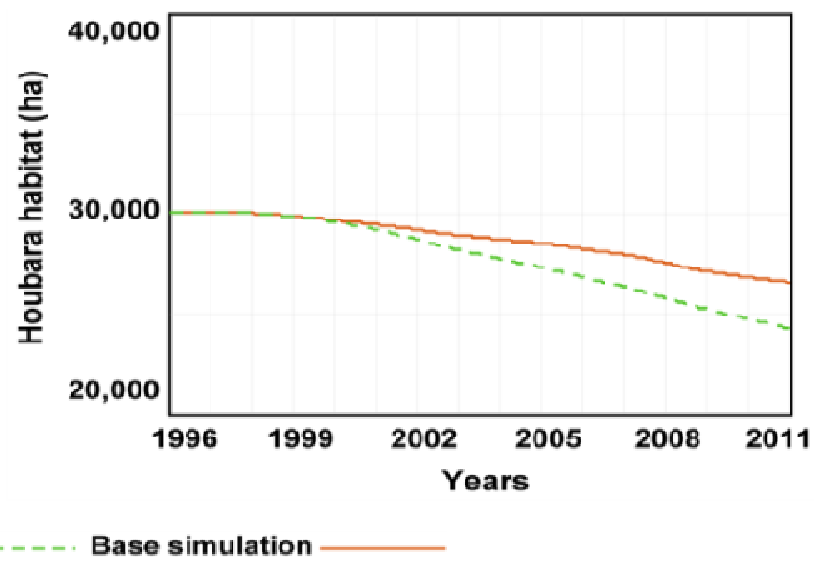

The comparison of the simulation results with the observed data constitutes a measure of the goodness of fit and, therefore, of the ability of the model to track the actual behaviour of the system and to capture its key questions (Martínez-Moyano \& Richardson, 2013). Figure 5 shows the simulation results for some of the key variables of the model.

The results for the 20 variables with available observed series (Table 3) show similar values for the two statistics determined in this work: the mean absolute percentage error (MAPE) and the normalised root mean square error (NRMSE). Of the variables, 90\% have an excellent-to-good degree of fit (MAPE <20\%), according to Goh and Law (2002), whereas $10 \%$ have a degree of fit that is only acceptable, according to these authors (MAPE between $20 \%$ and $30 \%$ ).

Regarding the NRMSE, $85 \%$ of the variables show an excellent-to-good degree of fit according to Andarizan et al. (2011) and Sepaskhah et al. (2013), who proposed the same intervals. 
Figure 5: Observed data ${ }^{4}$ and simulation results between 1996 and 2011. a) Tourist equivalent population (etp). b) Resident population. c) Urban land area. d) Active gavias. e) Houbara habitat. f) Egyptian vulture population.

a)

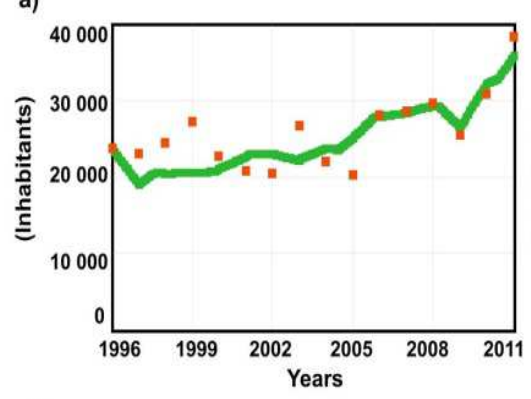

d)

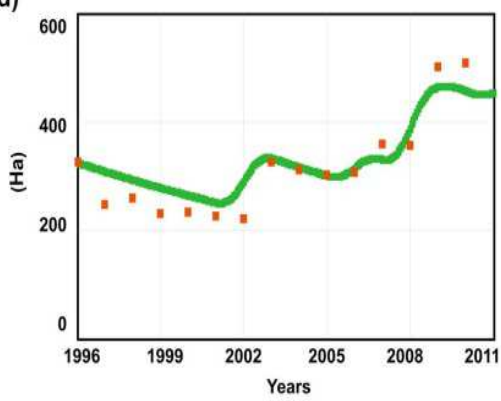

b)

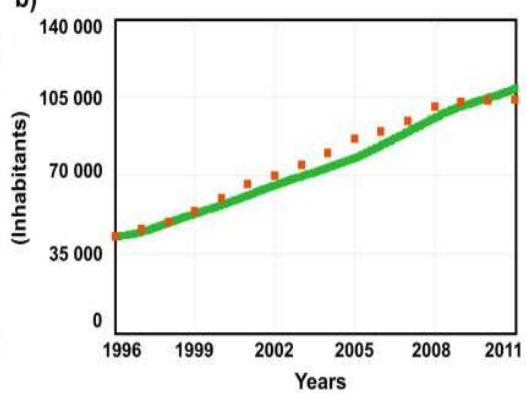

e)

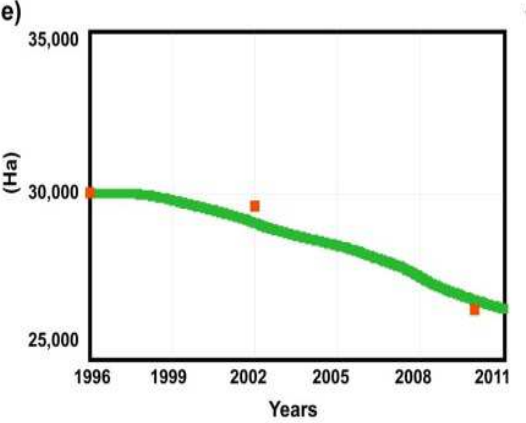

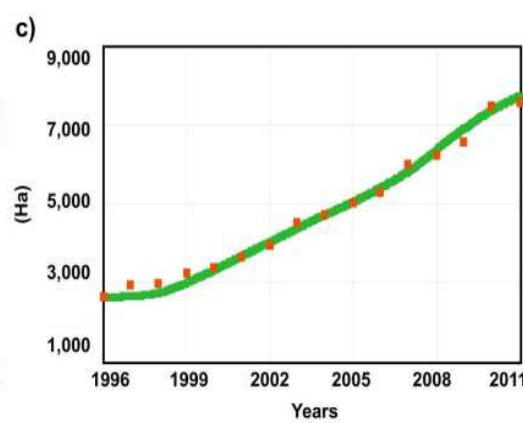

f)

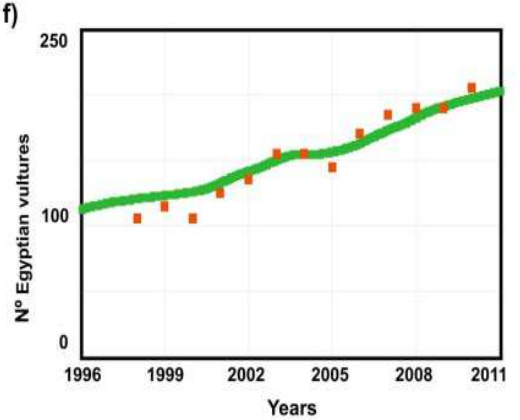

Observed data

Simulation results

The model successfully passed such testing procedures for the period 1996-2011, which supports the ability of the model to track the behaviour of the SES of Fuerteventura. For more thorough description of the model structure and model testing, see Banos-González et al. (2015).

In this work, the model was applied in order to analyse the vulnerability of the island to external changes, such as climate change, as well as to assess some policy measures. For this purpose, the set of indicators and their thresholds shown in Table 1 were used. Table 4 shows the simulation results for each indicator under the Business as Usual (BAU) simulation, the two climatic scenarios and the two policy measures.

\footnotetext{
${ }^{4}$ Observed data sources: For figures 5a) and 5b): ISTAC (2014). For figures 5c) and 5d): ISTAC (2013); Cadastre (2012); GRAFCAN (2011). For figure 5d): Lorenzo et al. (2004); Carrascal et al. (2008); Schuster et al. (2012). For figure 5f): Palacios (2000); Donázar et al. (2002); Díez et al. (2008); Mallo and Díez (2009, 2010).
} 
Table 3: Detailed results of the goodness of fit test for the 20 variables with available series of observed data.

\begin{tabular}{|l|l|l|l|}
\hline VARIABLES & n & MAPE (\%) & NRMSE (\%) \\
\hline Resident population & 16 & 4.300 & 5.458 \\
\hline Births & 12 & 6.220 & 8.624 \\
\hline Immigration & 16 & 26.184 & 23.384 \\
\hline Emigration & 16 & 32.699 & 31.650 \\
\hline Tourist equivalent population & 16 & 9.517 & 12.035 \\
\hline Tourist accommodation capacity & 16 & 7.287 & 9.400 \\
\hline Occupancy rate & 16 & 8.705 & 10.847 \\
\hline Tourist employment & 13 & 5.386 & 6.634 \\
\hline Houbara habitat & 3 & 0.979 & 1.531 \\
\hline Egyptian vulture population & 13 & 4.539 & 5.080 \\
\hline Urban built-up area & 16 & 2.335 & 2.840 \\
\hline Tracks & 3 & 1.059 & 1.730 \\
\hline Roads & 3 & 0.714 & 1.051 \\
\hline Active crops area & 15 & 10.137 & 11.398 \\
\hline Irrigated crops area & 15 & 11.755 & 13.698 \\
\hline Active gavias area & 15 & 10.492 & 11.550 \\
\hline Natural vegetation area & 3 & 0.280 & 0.446 \\
\hline Golf courses area & 15 & 10.01 & 24.45 \\
\hline Vehicles fleet & 12 & 4.574 & 4.145 \\
\hline Electric energy consumption & 14 & 4.977 & 7.142 \\
\hline n: Number of observed data & & & \\
\hline
\end{tabular}


Table 4: Simulation results for the sustainability indicators under the BAU, scenarios and measures simulations.

\begin{tabular}{|c|c|c|c|c|c|c|}
\hline \multirow{2}{*}{ INDICATOR } & \multirow{2}{*}{ THRESHOLDS } & \multirow{2}{*}{ BAU } & \multicolumn{2}{|c|}{$\begin{array}{l}\text { CLIMATE CHANGE } \\
\text { SCENARIOS }\end{array}$} & \multicolumn{2}{|c|}{$\begin{array}{c}\text { POLICY } \\
\text { MEASURES }\end{array}$} \\
\hline & & & $\mathbf{A 2}$ & B2 & M.I & M.II \\
\hline $\begin{array}{l}\text { Ratio between tourist } \\
\text { accommodation and } \\
\text { resident population (ear) }\end{array}$ & $<0.97$ & 0.46 & 0.46 & 0.46 & 0.46 & 0.42 \\
\hline $\begin{array}{l}\text { Artificial land proportion } \\
(\text { alp })\end{array}$ & $<20$ & 9.78 & 9.78 & 9.78 & 9.78 & 7.55 \\
\hline $\begin{array}{l}\text { High quality vegetation } \\
\text { proportion }(h q p)\end{array}$ & $\begin{array}{c}\text { LCA> } \\
0.14\end{array}$ & 0.05 & 0.01 & 0.01 & 0.05 & 0.05 \\
\hline Overgrazing indicator $(o i)$ & $<1$ & 0.86 & 0.96 & 1.0 & 0.86 & 0.84 \\
\hline $\begin{array}{l}\text { Houbara habitat proportion } \\
(h h p)\end{array}$ & LCA $>0.75$ & 0.74 & 0.74 & 0.74 & 0.74 & 0.83 \\
\hline $\begin{array}{l}\text { Egyptian vulture population } \\
\text { proportion }(e v p)\end{array}$ & $\mathrm{LCA}>0.75$ & 1.59 & 1.59 & 1.59 & 1.59 & 1.6 \\
\hline $\begin{array}{l}\text { Per capita primary energy } \\
\text { consumption }(p e p c)\end{array}$ & $<42$ & 262.73 & 262.73 & 262.73 & 256.46 & 283.01 \\
\hline $\begin{array}{l}\text { Per capita } \mathrm{CO}_{2} \text { emissions } \\
\left(\mathrm{CO}_{2} \mathrm{pc}\right)\end{array}$ & $<9.52$ & 15.98 & 16.11 & 16.16 & 15.82 & 17.63 \\
\hline $\begin{array}{l}\text { Share of renewable energy } \\
\text { (ser) }\end{array}$ & $>0.2$ & 0.01 & 0.01 & 0.01 & 0.02 & 0.01 \\
\hline
\end{tabular}

Application of the model: how do sustainability indicators behave?

The results under BAU show that the ratio between tourist accommodation and the resident population (ear) would decline around 17\% between 2012 and 2025 (Figure 6a). This indicator would not exceed its sustainability threshold under any of the simulations analysed. Under measure II (M.II), tourist accommodation and the resident population, numerator and denominator of the ear, would decrease almost $33 \%$ and $27 \%$, respectively, compared to BAU. This bigger decrease in the numerator would lead to an improvement of this indicator of around $8 \%$ under M.II, with respect to BAU, by 2025 (Table 4).

The artificial land proportion (alp) would almost double between 2012 and 2025 under BAU (Figure 6b). However, it would remain far from its sustainability threshold in all the simulations analysed. Under M.II, the alp would improve around $23 \%$, relative to BAU, since it is expected that this measure would slow down the land uptake processes.

For the high quality vegetation proportion (hqp), the BAU simulation results show a worsening of around $64 \%$ between 2012 and 2025. Under the A2 and B2 scenarios, this reduction would be around $77 \%$ and $85 \%$ greater, respectively, than with BAU (Figure 6c). A slight improvement, around 4\%, would be expected under M.II. Nevertheless, its sustainability threshold would be systematically exceeded under all the simulations analysed. 
Figure 6. Simulation results under BAU, climate change scenarios and two policy measures for the selected sustainability indicators.
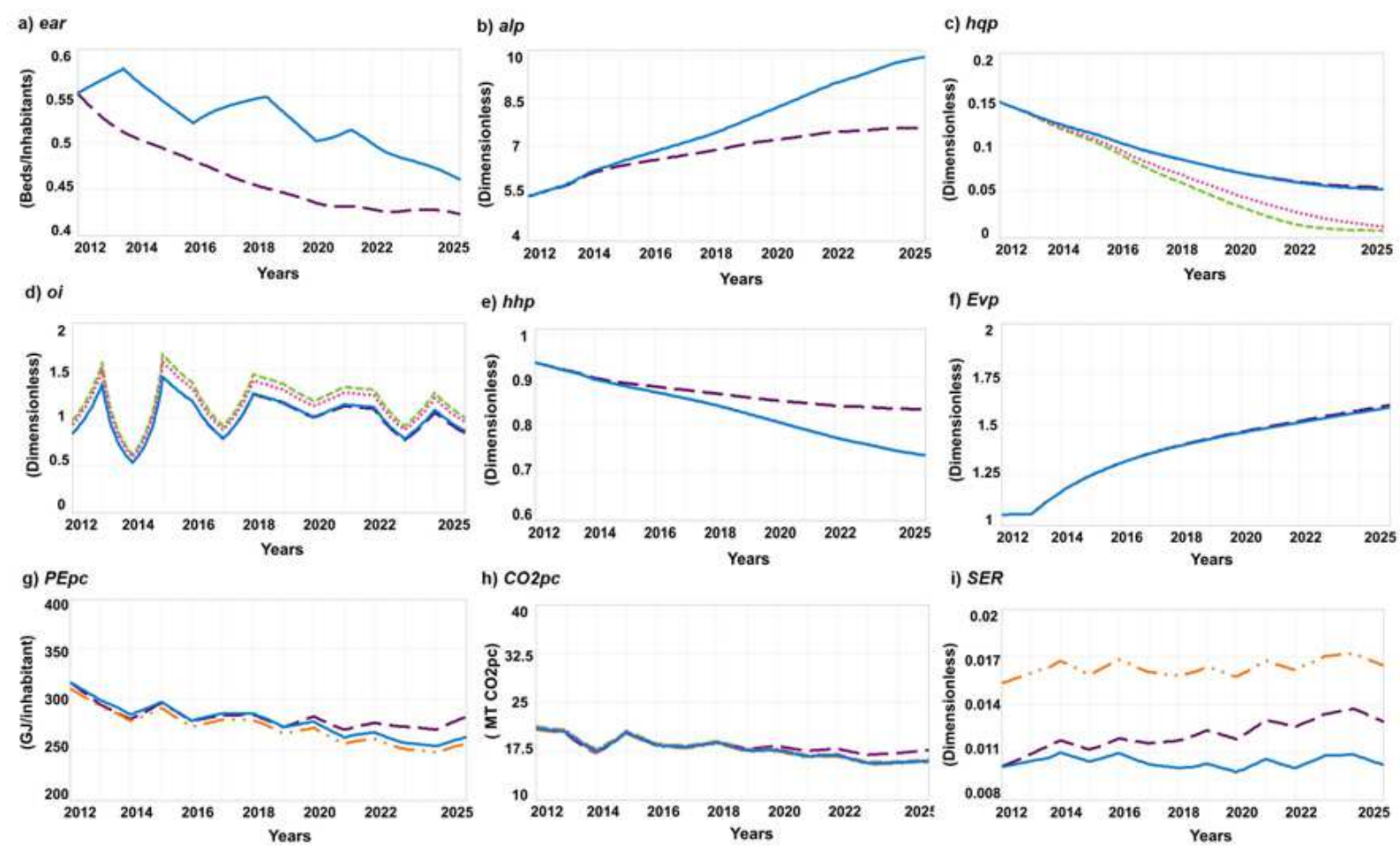

BAU

B2 --

Measure

Measure II -

a) ear: Ratio between tourist accommodation and the resident population; b) alp: Artificial land proportion; c) hqp: High quality vegetation proportion; d) oi: Overgrazing index; e) $h h p$ : Houbara habitat proportion; f) evp: Egyptian vulture population proportion; g) pepc: Per capita primary energy consumption; h) $\mathrm{CO}_{2} p c$ : Per capita $\mathrm{CO}_{2}$ emissions; i) ser: Share of renewable energy.

Under BAU, the oi would worsen almost $4 \%$ over the period 2012-2025. An additional worsening of around $11 \%$ and $16 \%$ would be expected by 2025 under A2 and B2, respectively, whereas a slight improvement, $2.5 \%$, is shown under M.II (Figure 6d). The threshold would be exceeded at certain points of the simulation period, but not in 2025 .

The loss of the $h h p$ between 2012 and 2025 would be almost $21 \%$ under BAU. Under M.II, an improvement of around $13 \%$ would be expected, in comparison with BAU (Figure $\underline{6 e})$. The simulation results show that this threshold would be systematically overcome, unless M.II was implemented.

The proportion of Egyptian vultures (evp) could almost double in the period 20122025, due, in part, to the increase in grazing cattle on the island. Moreover, this indicator would slightly improve (by almost 1\%) under M.II (Figure 6f). Its threshold would not be exceeded under any simulation.

The results show that under BAU the total primary energy consumption and the total emissions of $\mathrm{CO}_{2}$ would increase by around $36 \%$ and $25 \%$, respectively, on Fuerteventura between 2012 and 2025. However, the per capita indicators, pepc and $\mathrm{CO}_{2} p c$, would improve between 2012 and 2025 (Figures 6g and 6h). The expected rise of the share of renewable power production (ser) on the island would be around 1\% under BAU. Under M.I -in which 
the power demand of desalination processes would be met by renewable sources- the pepc and $\mathrm{CO}_{2} \mathrm{pc}$ would fall by around $2.4 \%$ and $1 \%$, respectively, relative to BAU. The ser would increase by around $61 \%$ (Figure 6i), although its impact on the total energy system would be rather small. Under M.II, increases in these three energy-related indicators would be expected, in relation to the reduction of the population (both resident and tourist equivalent). Concerning the A2 and B2 scenarios, slight increases in $\mathrm{CO}_{2} p c(0.8 \%$ and $1.1 \%$, respectively, compared to BAU) would be expected, probably related to a potential loss of $\mathrm{CO}_{2}$ sequestration. As shown in Table 4, these three indicators would exceed their thresholds under all the simulations considered.

\section{Application of the FSM as the basis to develop a dynamic model of El Hierro}

The integral model of the sustainability of the island of Fuerteventura (FSM) has been used as a basis to develop the sustainability model of the island of El Hierro (HSM). Although the ongoing development of the HSM is currently in the phase of quantitative formulation, in this section we briefly describe the main points of the conceptual model.

Figure 7: Overview of the El Hierro sustainability model, showing the key variables of the five sectors.

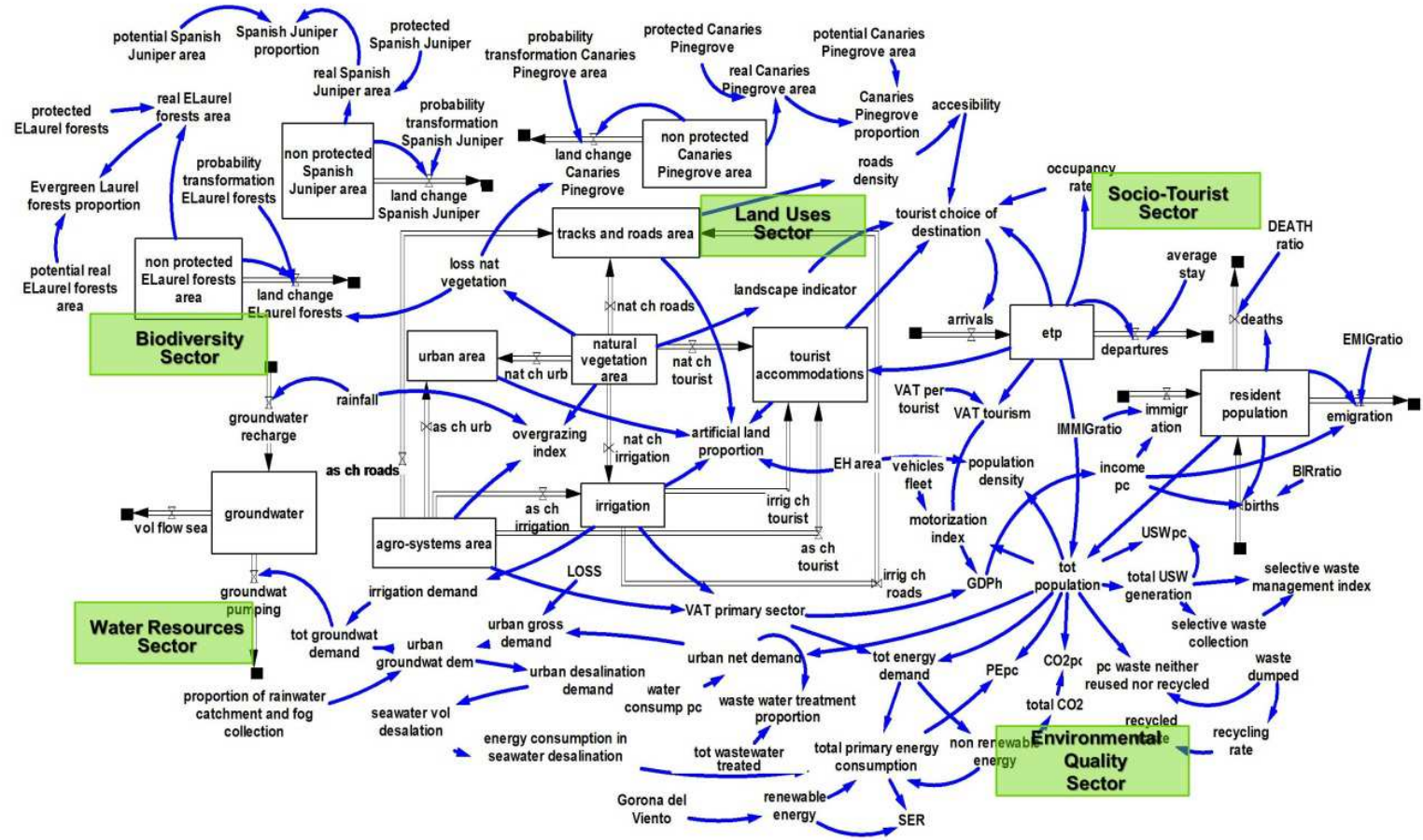

The construction of the HSM has followed the methodological approach shown in Figure 2. Like the FSM, it is structured in five sectors: socio-tourist, land uses, biodiversity, environmental quality and water resources (Figure 7). It includes 413 model variables, 37 of which represent sustainability indicators (Table 2). The indicators mainly derive from two reports: Government of the Canary Islands (2005) and El Hierro Cabildo (2006). Among the 
71 potential indicators extracted from these reports, the 37 indicators selected possess the essential features suggested in this manuscript, as well as the reusability criteria, since they are mostly the set of indicators integrated in the FSM. This might facilitate a comparative assessment of these two islands. Nevertheless, this is not addressed in this paper.

\section{Discussion}

The Fuerteventura sustainability model allows the understanding of the main components of this socio-ecological system, their changes over time and the interactions between sustainability indicators and other factors. This may help to improve the diagnosis and decision-making processes, as well as the assessment of sustainable policies.

The results of the model testing procedures support the ability of the model to track the main changes occurred in Fuerteventura over 1996-2011 and their implications for sustainability. The tourist activity has been one of the key factors in the extraordinary population growth which has taken place on the island (Figure 5). The rise in both resident and tourist equivalent population represents a driving factor for the land use change and the natural resources consumption, such as energy and water. In that sense, the seawater desalination, the main source of water on the island, has enabled to overcome the limitations of water scarcity on the socioeconomic activities. However, the strong dependency of water availability on energy consumption $-80 \%$ of total water demand is covered by seawater desalination-, implies a high vulnerability of the whole socio-ecological system, even for basic needs, to socioeconomic changes such as those in the energy policies and markets (Kruyt et al., 2009).

The simulation results support the existence of some trade-offs between environmental aims under the same management measure, in which the optimisation of some aims implies the inhibition of the achievement of others (MEA, 2005). Regarding the flagship species sector, the model has allowed the analysis of the changes in two key endangered species, linked to the dynamics of their main threatening factors. The model shows that measures aimed at restoring abandoned gavias (Fuerteventura Cabildo, 2009), and recovering some ecosystem services provided by this traditional agro-system (Díaz et al., 2011), would lead to the loss of houbara habitat, since abandoned gavias are part of its secondary habitat (Carrascal et al., 2008).

Moreover, measures aimed at controlling the loss of high quality vegetation, such as a reduction of grazing, might lead to negative impacts on the island population of the Egyptian vulture (Donázar et al., 2002; Gangoso et al., 2006), since cattle remains constitute the basis of the vulture's diet.

The existence of potential trade-offs should be taken into account in the decision making, in order to achieve more sustainable management of SES (Vidal-Legaz et al., 2013). In this context, SDMs provide a useful tool to improve the integral diagnosis of the socioecological problems and, therefore, to reduce conflicts between management options.

Moreover, a real tool for sustainable management in SES should have the capacity to deal with changes in external drivers (Folke et al., 2005). The FSM has incorporated a preliminary assessment of the vulnerability of this socio-ecological system to two climate change scenarios (A2 and B2), which could be incorporated into the management decisionmaking process to improve the island's capacity to adapt to and withstand external shocks. 
The simulation results (Table 4) show that under both climate change scenarios, five indicators would exceed their sustainability thresholds (hqp, hhp, pepc, ser and $\mathrm{CO}_{2} p c$ ) in 2025, the same number as under BAU. Nevertheless, three out of nine indicators would worsen, when compared to BAU ( $h q p, o i, \mathrm{CO}_{2} p c$ ). These results, although preliminary, point to the vulnerability of this island to climate change, as suggested by Lloret and GonzálezMancebo (2011) and Fernandes et al. (2015), so urgent measures should be addressed.

Furthermore, two policy measures proposed by other agents have been assessed in terms of how a set of indicators included in the model would behave. The establishment of thresholds for every indicator is a clear step forward in sustainability, since they represent a reference for decisions in terms of sustainability (Rodríguez-Rodríguez and Martínez-Vega, 2012). As shown in Table 4, four of the nine indicators considered would systematically exceed their thresholds under the measures analysed (hqp, pepc, ser and $\mathrm{CO}_{2} p c$ ).

Regarding the hqp, the degradation of the high quality vegetation is one of the processes on the island that most worries the Scientific Committee of the Reserve (pers. com.) and, as shown, it could worsen under climate change scenarios. The simulation results for 2012-2025 do not support continued vegetation degradation caused by livestock (Figure 6d). Nevertheless, it seems that, during especially intense droughts, there would be degradation of high quality vegetation due to overgrazing, as suggested by numerous authors (Gangoso et al., 2006; Nogales et al., 2006; Schuster et al., 2012). The loss of the hqp may be related also to land use changes due to socio-touristic dynamics. In this sense, measure II would slightly improve this indicator.

The other three indicators which would also exceed their thresholds under all the measures considered are pepc, ser and $\mathrm{CO}_{2} p c$, even though measure I (M.I) explicitly addresses their improvement. While M.I would yield better results than BAU for these indicators, it seems insufficient to meet the general objectives set out regarding the European policies on energy and climate change (EC, 2015). More ambitious measures and policies are needed, particularly on islands - where the provision of energy from fossil fuels entails a number of difficulties, such as the economic and environmental costs of using fossil fuels and the dependence on transportation of the fuel itself (Becken et al., 2003; Kuo \& Chen, 2009).

With regards to the houbara habitat proportion $(h h p)$, M.II would produce an improvement in this indicator in relation to its threshold. The levelling-off of the expected land uptake under M.II, as suggested by previous authors (Lorenzo, 2004; Carrascal et al., 2008), would have a certain positive effect on the houbara habitat, reducing its loss: thus, its threshold would not be exceeded.

Besides $h h p$, another six indicators would improve under M.II, compared to BAU (ear, alp, oi, evp, hqp and ser), although the latter two would still exceed their thresholds. Two indicators would worsen under this measure, pepc and $\mathrm{CO}_{2} p c$. Despite certain reductions in the overall consumption and emissions under this measure, the decrease in the population - the denominator of these indicators - expected under M.II would lead to their worsening.

In this sense, it should be pointed out that relative indicators, such as the per capita indicators, which might improve between years 2012 and 2025 (Figures 6h and 6i), do not always give sound information about sustainability when considered alone. These efficiency indicators and their changes with time should be taken with caution (Hanley et al., 2009), to avoid misunderstandings and errors in the diagnosis (Mori \& Christodoulou, 2012).

All simulation results for three indicators (ear, alp and evp) show that they would remain far from their thresholds, which could mean a good score in terms of sustainability. 
This might be interpreted as a clear possibility to accede to a rising demand for tourist and residential infrastructures on the island. Nevertheless, in order to sustain a moderate increase in arrivals and income and, at the same time, protect the stakeholders from the uncontrolled growth experienced by other islands (Dodds, 2007; Santana-Jiménez \& Hernández, 2011), restrictions to new tourist-related constructions should be maintained.

By means of the assessment of indicators under policy measures, the FSM has highlighted one of the main challenges: the binomial water-energy. Partial measures do not seem to be enough to approach sustainability on this island, which has an increasing demand for water and energy. More ambitious measures should be adopted regarding energy, as suggested by Veigas et al. (2014) or as has occurred in El Hierro (Iglesias \& Carvallo, 2011).

Regarding the fourth objective set out in the introduction, reuse, sharing, replication and reproducibility are, for some authors, desirable principles in environmental modelling activities (Jasny et al., 2011). However, the reuse of integrated models is very limited in practice (Granell et al., 2013). In this work, the FSM has been used as the basis to develop a dynamic model of the neighbouring island, El Hierro, extrapolating all features common to both island SES. Although the HSM is still under development, and no tested quantitative results are available, its construction on the basis of a pre-existing model offers some insights.

The development of a tested and calibrated model of a complex socio-ecological system is always resource intensive. Thus, the ability to reuse an application -in part or as a whole- can result in significant resource savings, more problems being solved and more decisions being reached (Liank et al., 2013). In the elaboration of the El Hierro sustainability model, the modelling process for the FSM was followed, using the structure of the conceptual model as much as possible. Moreover, the sustainability indicators integrated in the model were selected following the features underlined by Bell and Morse (2008), but adding the reusability criteria.

Still, since the context-specific nature of problems in SES naturally demands contextspecific models and tools, the application of integral models is usually oriented to the generation of problem solutions (Oliva, 2003; Galic et al., 2012). Therefore, model outputs cannot be easily transferred between contexts without a reconsideration of the model assumptions, parameterisation and intended purpose.

According to Verburg et al. (2015), the specific questions to be answered using the models are variable and dynamic. Thus, we support the need for problem-specific perspectives to deal with the complexity of each real socio-ecological system, as other studies have proposed (González et al., 2008; Li et al., 2012; Martínez-Fernández et al., 2013) and as shown in this work by the Fuerteventura case study. On-going and future work will develop in depth the El Hierro sustainability model, in order to generate a real tool for stakeholders and decision makers, capable of addressing the El Hierro-specific challenges.

\section{Conclusion}

As a contribution to the sustainability assessment of island socio-ecological systems, an integral dynamic model and some of its applications are presented in this paper.

The Fuerteventura sustainability model (FSM), calibrated for the 1996-2011 period, enabled the integration of the main sustainability indicators, which facilitated a dynamic analysis of this socio-ecological system as well as the identification and quantification of 
potential trade-offs between different sustainability indicators - which improve the diagnosis and decision-making processes.

One of the applications of the FSM has allowed the analysis of the behaviour of nine indicators under a set of scenarios and measures, over the period 2012-2025, in relation to their sustainability thresholds.

At the end of this period, four of the nine indicators (hqp, pepc, $\mathrm{CO}_{2} p c$ and ser) would exceed their thresholds under all the simulations. Under the climate change scenarios A2 and $\mathrm{B} 2$, three of the nine indicators ( $h q p, \mathrm{CO}_{2} p c$ and $o i$ ) would worsen, relative to BAU. Regarding the policy measures, M.I -all the energy demand of desalination being provided by renewable sources- would improve the outputs of three indicators (pepc, $\mathrm{CO}_{2} p c$ and $\mathrm{ser}$ ). Under M.II -limitation of the construction of new tourist accommodation- seven indicators would improve in comparison with BAU (ear, alp, hqp, oi, hhp, evp and ser), while two (pepc and $\mathrm{CO}_{2} \mathrm{pc}$ ) would worsen. These results, although preliminary, underline -on the one handthe vulnerability of this island socio-ecological system to climate change and the need to impose urgent measures to mitigate its effects. On the other hand, there is also a lack of more ambitious measures to achieve sustainability objectives regarding the energy issues.

The FSM has been shown to be useful as the basis to develop a dynamic model of the neighbouring island of El Hierro, extrapolating all the conceptual features common to both island SES.

\section{References}

Action Plan of the Fuerteventura Biosphere Reserve. (2013). Retrieved from http://gestion.cabildofuer.es/fuerteventurabiosfera/

Andarizan, B., Bannayanb, M., Stedutoc, P., Mazraeham H., Baratid, M.E., Baratie, M.A., \& Rahnama, A. (2011). Validation and testing of AquaCrop model under full and deficit irrigated wheat production in Iran. Agricultural Water Management, 100(1), 1-8.

Anderies, J.M., Janssen M.A., \& Ostrom, E. (2004). A framework to analyze the robustness of social-ecological systems from an institutional perspective. Ecology and Society, 9(1), 18.

Baldacchino, G. (2006). Islands, island studies, Island Studies Journal. Island Studies Journal, 1(1), 3-18.

Baldacchino, G. (2013). Book Reviews: Insularité et développement durable [Insularity and sustainable development] by F. Taglioni (Ed.); La Corse et le développement durable [Corsica and sustainable development] by M.A. Maupertuis (Ed.); Le Québec des îles [The Islands of Quebec] by L. Guay. In Island Studies Journal, 8(1), 191-193

Banos-González, I., Martínez-Fernández, J. \& Esteve, M.A. (2015). Dynamic integration of sustainability indicators in insular socio-ecological systems. Ecological Modelling, 306(Special Issue: Ecological Modelling for Ecosystem Sustainability), 130-144.

Banos-González, I., Terrer, C., Martínez-Fernández, J., Esteve, M.A, \& Carrascal, L.M. (2016). Dynamic modelling of the potential habitat loss of endangered species: the case of the Canarian Houbara Bustard (Chlamydotis undulata fuerteventurae). European Journal of Wildlife Research. In press. 
Banos-González, I., Martínez-Fernández, J., \& Esteve, M.A. (2013). Simulación dinámica de sistemas socio-ecológicos: sostenibilidad en Reservas de la Biosfera. Ecosistemas, 22(3), 74-83.

Barlas, Y. (1996). Formal aspects of model validity and validation in system dynamics. System dynamics review, 12(3), 183-210.

Becken, S., Simmons, D.G. \& Frampton, C. (2003). Energy use associated with different travel choices. Tourism Management, 24(3), 267-277.

Bell, S., \& Morse, S. (2005). Holism and understanding sustainability. Systemic Practice and Action Research, 18(4), 409-426.

Bell, S., \& Morse, S. (2008). Sustainability indicators: Measuring the immeasurable. London: Earthscan.

BirdLife International. (2004). Birds in the European Union: A status assessment. The Netherlands: BirdLife International. Retrieved from http://www.lpo.fr/images/liste_rouge_europeene/birds_in the_eu.pdf

Bueno, C., \& Carta, J.A. (2005). Technical-economic analysis of wind-powered pumped hydrostorage systems. Part II: model application to the island of El Hierro. Solar Energy, 78(3), 396-405.

Cabrera, M.C., \& Custodio, E. (2012). The Canary Islands. In L. De Stefano \& M.R. Llamas (Eds.), Water, agriculture and the environment in Spain: Can we square the circle? (pp. 281-291). CRC Press. Taylor and Francis.

Cáceres, Y. (2010). Sustainability indicators system for Fuerteventura Biosphere Reserve. Fuerteventura Biosphere Reserve.

Cadastre (2012). Cadastral statistics. Retrieved from www.catastro.meh.es

Carrascal, L.M., Palomino, D., Seoane, J., \& Alonso, C.L. (2008). Habitat use and population density of the houbara bustard Chlamydotis undulata in Fuerteventura (Canary Islands). African Journal of Ecology, 46(3), 291-302.

CEDEX [Centro de Estudios y Experimentación de Obras Públicas] (2011). Evaluación del impacto del cambio climático en los recursos hídricos en régimen natural. Encomienda de Gestión de la Dirección General del Agua al CEDEX para el estudio del cambio climático en los recursos hídricos y las masas de agua. Ministerio de Medio Ambiente y Medio Rural y Marino. Retrieved from http://www.magrama.gob.es/es/cambioclimatico/publicaciones/publicaciones /Memoria_encomienda_CEDEX_tcm7$\underline{165767 . p d f}$

CIAFV [Fuerteventura Island Water Council]. (2009). Retrieved from http://www.aguasfuerteventura.com/

Cruz, A. (2009). Tourist attraction factors: similarities and differences in major destinations in the Caribbean Islands. TURyDES, 2(6), 1-18.

del Arco Aguilar, M.J., González-González, R., Garzón-Machado, V., \& Pizarro-Hernández B. (2010). Actual and potential natural vegetation on the Canary Islands and its conservation status. Biodiversity and Conservation, 19(11), 3089-3140.

Denis, G.S., \& Parker, P. (2009). Community energy planning in Canada: The role of renewable energy. Renewable and Sustainable Energy Reviews, 13(8), 2088-2095. 
Díaz, F.J., Tejedor, M., Jiménez, C., \& Dahlgren, R.A. (2011). Soil fertility dynamics in runoff-capture agriculture, Canary Islands, Spain. Agriculture, Ecosystems \& Environment, 144(1), 253-261.

Diedrich, A., Huguet, P.B. \& Subirana, J.T. (2011). Methodology for applying the limits of acceptable change process to the management of recreational boating in the Balearic Islands, Spain (Western Mediterranean). Ocean \& Coastal Management, 54(4), 341351.

Díez, C., Mallo, M. \& Donázar, J.A. (2008). Monitoring of Egyptian vulture's population (Neophron ercnopterus majorensis) in Fuerteventura (Canary Islands). Final report. Estación Biológica de Doñana (EBD)-Consejo Superior de Investigaciones Científicas.

Dodds, R. (2007). Malta's tourism policy: standing still or advancing towards sustainability. Island Studies Journal, 2(1), 47-66.

Donázar, J.A., Palacios, C.J., Gangoso, L., Ceballos, O., González, M.J. \& Hiraldo, F. (2002). Conservation status and limiting factors in the endangered population of Egyptian vulture (Neophron percnopterus) in the Canary Islands. Biological Conservation, 107(1), 89-97.

EC (2008). European Commission. Communication from the Commission-energy efficiency: delivering the 20\% target. COM 2008, 772 final.

EC (2015). European Commission, Climate Action, EU Action 2030. Retrieved from http://ec.europa.eu/clima/policies/2030/index_en.htm

EEA [European Environmental Agency] (2012). Environmental indicator report 2012Ecosystem resilience and resource efficiency in a green economy in Europe. Retrieved from http://www.eea.europa.eu/publications/environmental-indicator-report-2012

El Hierro Cabildo (2006). Plan for the sustainable development of El Hierro Island. Retrieved from http://www.elhierro.es/files/Plan\%20desarrollo\%20sostenible/PDS.pdf

Fernandes, J.P., Guiomar, N. \& Gil, A. (2015). Strategies for conservation planning and management of terrestrial ecosystems in small islands (exemplified for the Macaronesian islands). Environmental Science \& Policy, 51(1), 1-22.

Folke, C., Hahn, T., Olsson, P. \& Norberg, J. (2005). Adaptive governance of social-ecological systems. Annual Review of Environmental Resources, 30, 441-473.

Fong, W.K., Matsumoto, H. \& Lun, Y.F. (2009). Application of System Dynamics model as decision making tool in urban planning process toward stabilizing carbon dioxide emissions from cities. Building and Environment, 44(7), 1528-1537.

Forrester, J.W. (1961). Industrial dynamics. Waltham MA: Pegasus Communications.

Fuerteventura Cabildo (2009). Retrieved from http://www.cabildofuer.es/portal/

Galic, N., Schmolke, A., Forbes, V., Baveco, H., \& van den Brink, P.J. (2012). The role of ecological models in linking ecological risk assessment to ecosystem services in agroecosystems. Science of the Total Environment, 415, 93-100.

Gallopin, G.C. (1997). Indicators and their use: information for decision-making. In B. Moldan, S. Billharz \& R. Matravers (Eds.), SCOPE 58 Sustainability indicators: Report on the project on indicators of sustainable development. Chichester: John Wiley \& Sons. 
Gangoso, L., Donázar, J.A., Scholz, S., Palacios, C.J. \& Hiraldo, F. (2006). Contradiction in conservation of island ecosystems: plants, introduced herbivores and avian scavengers in the Canary Islands. Biodiversity \& Conservation, 15(7), 2231-2248.

Garín-Muñoz, T. (2006). Inbound international tourism to Canary Islands: a dynamic panel data model. Tourism Management, 27(2), 281-291.

Goh, C., \& Law, R. (2002). Modeling and forecasting tourism demand for arrivals with stochastic nonstationary seasonality and intervention. Tourism Management, 23(5), 499510.

González, J.A., Montes, M.C., Rodríguez, J. \& Tapia, W. (2008). Rethinking the Galapagos Islands as a complex social-ecological system: implications for conservation and management. Ecology and Society, 13(2), 13.

Government of the Canary Island (2005). Indicators for monitoring guidelines of the general planning of the Canary Islands. Retrieved from http://www.gobiernodecanarias.org/cmayot/desarrollosostenible/directricesdeordenacion /pdf/estsistemaindicadores.pdf

Government of the Canary Islands (2008). Metodología para la aplicación práctica de la apreciación y evaluación de los factores determinantes de la capacidad de carga. Especialmente en zonas turísticas. Government of the Canary Islands. Retrieved from http://www.fecam.es/documentos/areas/turismo_transportes/CCTGuia.pdf

Government of the Canary Islands (2010). Viceconsejería de Turismo. Estadísticas y Estudios. Pasajeros por vía aérea procedentes del extranjero. Retrieved from http://www.gobiernodecanarias.org/presidencia/turismo/estadisticas_y_estudios/Pasajer os_procedentes_del_extranjero_segxn_Pais_de_origen_index-bis.html

GRAFCAN. (2011). Mapa de Vegetación, Fuerteventura (2002/2003). Retrieved from http://www.idecan.grafcan.es

Granell, C., Schade, S. \& Ostländer, N. (2013). Seeing the forest through the trees: A review of integrated environmental modelling tools. Computers, Environment and Urban Systems, $41,136-150$.

Graymore, M.L., Sipe, N.G. \& Rickson, R.E. (2010). Sustaining human carrying capacity: a tool for regional sustainability assessment. Ecological Economics, 69(3), 459-468.

Halliday, A. \& Glaser, M. (2011). A Management Perspective on Social Ecological Systems: A generic system model and its application to a case study from Peru. Human Ecology Review, 18(1), 1-18.

Hanley, N., McGregor, P.G., Swales, J.K. \& Turner, K. (2009). Do increases in energy efficiency improve environmental quality and sustainability? Ecological Economics, 68(3), 692-709.

Herrera, C. \& Custodio, E. (2000). Saline water in Central Fuerteventura Island, Canary Islands, Spain. In XV Salt Water Intrusion, Meeting, Miedzyzdroje-Wolin Island, 80(1), 81-86.

Hidalgo, C., Ther, F., Saavedra, G. \& Díaz, A. (2015). Affordance of landscapes and economic socio-spatial networks in the Quinchao archipelago, Chile: a contribution to landscape research and island studies. Island Studies Journal, 10(1), 49-70.

Hodbod, J. \& Adger, W.N. (2014). Integrating social-ecological dynamics and resilience into energy systems research. Energy Research \& Social Science, 1, 226-231. 
Iglesias, G. \& Carballo, R. (2011). Wave resource in El Hierro: an island towards energy selfsufficiency. Renewable Energy, 36(2), 689-698.

ISTAC (2012). Labour Force Survey (1998-2012). Las Palmas de Gran Canaria (Spain). Retrieved from http://www.gobiernodecanarias.org/istac/temas_estadisticos/empleo/empleo/actividadec onomica/E30308A.html

ISTAC (2013). Agriculture. Las Palmas de Gran Canaria (Spain). Retrieved from http://www.gobiernodecanarias.org/istac/temas_estadisticos/sectorprimario/agricultura/a gricultura/

ISTAC (2014). Demographic figures (2000-2014). Las Palmas de Gran Canaria (Spain). Retrieved from http://www.gobiernodecanarias.org/istac/temas_estadisticos/demografia/

Jasny, B.R., Chin, G., Chong, L. \& Vignieri, S. (2011). Again, and again, and again ... Science, 334(6060), 1225-1225.

Johansson, T.B. \& Goldemberg, J. (2004). Energy and the Challenge of Sustainability Overview: 2004 Update, United Nations Development Programme, United Nations Department of Economic and Social Affairs, and World Energy Council. Retrieved from http://www.undp.org/seed/eap/activities/wea/

Jørgensen, S.E. (2013). The development of a carbon cycling model for the Danish island of Sams $\varnothing$ based on renewable energy. 19th ISEM Conference on Ecological Modelling for Ecosystem Sustainability in the context of Global Change. Toulouse, 28-31.

Kelly, R.A., Jakeman, A.J., Barreteau, O., Borsuk, M.E., ElSawah, S., Hamilton, S.H., ... \& Voinov, A.A. (2013). Selecting among five common modelling approaches for integrated environmental assessment and management. Environmental Modelling \& Software, 47, 159-81.

Kitrinou, E. \& Mytilini, L. (2014). Development of a behavioural framework for analyzing employment mobility decisions in island areas: the case of the Aegean Islands, Greece. Island Studies Journal, 9(2), 307-326.

Kruyt, B., van Vuuren, D.V., De Vries, H.J.M. \& Groenenberg, H. (2009). Indicators for energy security. Energy Policy, 37(6), 2166-2181.

Kuo, N.W. \& Chen, P.H. (2009). Quantifying energy use, carbon dioxide emission, and other environmental loads from island tourism based on a life cycle assessment approach. Journal of Cleaner Production, 17(15), 1324-1330.

Lesnoff, M., Corniaux, C. \& Hiernaux, P. (2012). Sensitivity analysis of the recovery dynamics of a cattle population following drought in the Sahel region. Ecological Modelling, 232(1), 28-39.

Li, F.J., Dong, S.C. \& Li, F. (2012). A system dynamics model for analyzing the ecoagriculture system with policy recommendations. Ecological Modelling, 227(1), 34-45.

Lloret, F. \& González-Mancebo, J.M. (2011). Altitudinal distribution patterns of bryophytes in the Canary Islands and vulnerability to climate change. Flora-Morphology, Distribution, Functional Ecology of Plants, 206(9), 769-781.

Lorenzo, J.A. (2004). Avutarda Hubara Canaria, Chlamydotis undulata fuertaventurae. In: Madroño A, González C, Atienza JC (Eds.), Libro rojo de las aves de España (pp. 207209). Madrid: Ministerio de Medio Ambiente-SEO/BirdLife. 
Mallo, M. \& Díaz, C. (2009). Egyptian vulture in Canary Islands. In J.C. del Moral (Ed.), Egyptian vulture in Spain: Breeding population in 2008 and census method. Madrid: $\mathrm{SEO} / \mathrm{BirdLife.}$

Mallo, M. \& Díez, C. (2010). Report on the conservation status of the Canarian Egyptian vulture (Neophron percnopterus majorensis) in Fuerteventura island (Canary Islands). Unpublished results. Estación Biológica de Doñana (EBD), Consejo Superior de Investigaciones Científicas.

Martín Fernández, C.S. (2009). Evolución del sistema turístico de la Isla de El Hierro (Canarias). Cuadernos de Turismo, 24(1), 111-133.

Martínez-Fernández, J., Esteve, M.A., Baños-González, I., Carreño, F. \& Moreno, A. (2013). Sustainability of Mediterranean irrigated agro-landscapes. Ecological Modelling, 248(1), 11-19.

Martínez-Moyano, I.J. \& Richardson, G.P. (2013). Best practices in system dynamics modeling. System Dynamics Review, 29(2), 102-23.

MEA [Millennium Ecosystem Assessment]. (2005). Ecosystems and Human Well-Being, Synthesis. London: Island Press. Retrieved from www.millenniumassessment.org/documents/document.356.aspx.pdf

Moldan, B., Janoušková, S. \& Hák, T. (2012). How to understand and measure environmental sustainability: Indicators and targets. Ecological Indicators, 17(1), 4-13.

Mori, K. \& Christodoulou, A. (2012). Review of sustainability indices and indicators: towards a new City Sustainability Index (CSI). Environmental Impact Assessment Review, 32(1), 94-106.

Nakicenovic, N. \& Swart, R. (2000). Special report on emissions scenarios. Cambridge: Cambridge University Press.

Nogales, M., Rodríguez-Luengo, J.L. \& Marrero, P. (2006). Ecological effects and distribution of invasive non-native mammals on the Canary Islands. Mammal Review, 36(1), 49-65.

Oliva, R. (2003). Model calibration as a testing strategy for system dynamics models. European Journal of Operational Research, 151(3), 552-568.

Palacios, C.J. (2000). Decline of the Egyptian Vulture (Neophron percnopterus) in the Canary Islands. Journal of Raptor Research, 34(1): 61.

Pérez, I, Tenza, A., Anadón, J.D., Martínez-Fernández, J., Pedreño, A. \& Giménez, A. (2012). Exurban sprawl increases the extinction probability of a threatened tortoise due to pet collections. Ecological Modelling, 245, 19-30.

Petrosillo, I., Costanza, R., Aretano, R., Zaccarelli, N. \& Zurlini, G. (2013). The use of subjective indicators to assess how natural and social capital support residents' quality of life in a small volcanic island. Ecological Indicators, 24, 609-620.

Pons, A., Salamanca, O.R. \& Murray, I. (2014). Tourism capitalism and island urbanization: tourist accommodation diffusion in the Balearics, 1936-2010. Island Studies Journal, 9(2), 239-258.

Rodríguez-Rodríguez, D. \& Martínez-Vega, J. (2012). Proposal of a system for the integrated and comparative assessment of protected areas. Ecological Indicators, 23, 566-572.

Santana-Jiménez, Y. \& Hernández, J.M. (2011). Estimating the effect of overcrowding on tourist attraction: The case of Canary Islands. Tourism Management, 32(2), 415-25. 
Schneider, F., Bonriposi, M., Graefe, O., Herweg, K., Homewood, C., Huss, M., ... \& Weingartner, R. (2014). Assessing the sustainability of water governance systems: the sustainability wheel. Journal of Environmental Planning and Management, 58(9), 1-24.

Schuster, C., Iglesias-Lebrija, J.J. \& Carrascal, L.M. (2012). Recent population trends of the houbara bustard in the Canary Islands: methods and conservation status. Animal Biodiversity and Conservation, 35(1), 125-139.

Sepaskhah, A.R., Amini-Nejad, M. \& Kamgar-Haghighi, A.A. (2013). Developing a dynamic yield and growth model for saffron under different irrigation regimes. International Journal of Plant Production, 7(3), 473-504.

Stankey, G.H., Cole, D.N., Lucas, R.C., Petersen, M.E. \& Frissell, S.S. (1985). The Limits of Acceptable Change (LAC) System for Wilderness Planning. Ogden UT: USDA Forest Service, Intermountain Forest and Range Experiment Station.

Sun, X.Y., Newham, L.T.H., Croke, B.F.W. \& Norton, J.P. (2012). Three complementary methods for sensitivity analysis of a water quality model. Environmental Modelling \& Software, 37(1), 19-29.

Torres Cabrera, J.M. (1995). The soil as a natural resource: degradation process and their impact on desertification of the island of Fuerteventura. Unpublished dissertation. La Laguna University, Spain.

UNEP [United Nations Environment Programme] (2002). Global environment outlook 3. London: Earthscan.

UNESCO (2000). Man and the Biosphere program. Biosphere reserve: El Hierro. Retrieved from http://www.unesco.org/new/en/natural-sciences/environment/ecologicalsciences/biosphere-reserves/europe-north-america/spain/isla-de-el-hierro/

UNESCO (2009). Retrieved from http://www.unesco.org/new/en/naturalsciences/environment/ecological-sciences/biosphere-reserves/europe-northamerica/spain/fuerteventura/

van Zeijl-Rozema, A., Ferraguto, L. \& Caratti, P. (2011). Comparing region-specific sustainability assessments through indicator systems: Feasible or not? Ecological economics, 70(3), 475-486.

Veigas, M., Carballo, R. \& Iglesias, G. (2014). Wave and offshore wind energy on an island. Energy for Sustainable Development, 22(1), 57-65.

Ventana System. (2011). Vensim ®. Retrieved from http://www.vensim.com

Verburg, P.H., Dearing, J.A., Dyke, J.G., van der Leeuw, S., Seitzinger, S., Steffen, W. \& Syvitski, J. (2015). Methods and approaches to modelling the Anthropocene. Global Environmental Change. In press. http://dx.doi.org/10.1016/j.gloenvcha.2015.08.007

Vidal-Legaz, B., Martínez, J., Sánchez Picón, A. \& Pugnaire, F. (2013). Trade-offs between maintenance of ecosystem services and socio-economic development in rural mountainous communities in southern Spain: a dynamic simulation approach. Journal of Environmental Management, 131, 280-297.

Wei, W., Álvarez, I. \& Martín, S. (2013). Sustainability analysis: viability concepts to consider transient and asymptotical dynamics in socio-ecological tourism-based systems. Ecological Modelling, 251, 103-113.

Zhang, J., Ji, M. \& Zhang, Y. (2015). Tourism sustainability in Tibet: forward planning using a systems approach. Ecological Indicators, 56, 218-228. 